\title{
Libra Project: Regulators Act on Global Stablecoins
}

Governments, regulatory authorities and standard-setting bodies started acting on global stablecoins triggered by the Libra announcement. Among the concerns expressed by the G7 and the G20 are risks to the stability of the financial system. The Financial Stability Board and the Financial Action Task Force have worked on regulatory issues and antimoney laundering ahead of the G20 summit in November 2020. Overall the Libra project has raised many questions on the regulatory front. Facebook had to revise the concept as Libra 2.0 and resubmit it for approval in April 2020. The European Commission announced a new regulation on Markets in Crypto-assets (MiCA) including stablecoins in September 2020 as part of a new Digital Finance Package. This opens the next chapter in a regulatory cat and mouse game.

\begin{abstract}
"Libra's mission is to enable a simple global currency and financial infrastructure that empowers billions of people" (Libra Association, 2019a, 1). On 18 June 2019, the Libra project, Facebook's new cryptocurrency structured as a 'stablecoin', was announced with an intended launch in early 2020 (Brühl, 2020, 54). The internet services provided by the Facebook group (including Facebook, Instagram, WhatsApp, Messenger) have a global reach of almost 3 billion users, alone 2.4 billion via Facebook. Not surprisingly, regulators and central banks at the international level have been concerned by the potential impact on investor protection, financial stability and market integrity (European Securities and Markets Authority, 2019, 33).
\end{abstract}

\section{Stablecoins}

The term stablecoin, as used by market participants, denotes crypto-assets that are supposed to have a stable

(C) The Author(s) 2020. Open Access: This article is distributed under the terms of the Creative Commons Attribution 4.0 International License (https://creativecommons.org/licenses/by/4.0/).

Open Access funding provided by ZBW - Leibniz Information Centre for Economics.

Oliver Read, Wiesbaden Business School, Hochschule RheinMain University of Applied Sciences, Germany.

Stefan Schäfer, Wiesbaden Business School, Hochschule RheinMain University of Applied Sciences, Germany. value over time (ECB Crypto-Assets Task Force, 2019, 14). The rise of stablecoins has been driven by the criticism on the significant volatility seen in the price of cryptocurrencies. Before 2019, stablecoins slowly started drawing the attention of researchers and regulators, especially in connection with central bank digital currencies, digital money and cross-border payments (Mancini-Griffoli et al., 2018).

Bullmann et al. $(2019,9)$ define stablecoins as "digital units of value that are not a form of any specific currency (or basket thereof) but rely on a set of stabilisation tools which are supposed to minimise fluctuations of their price in such currency". To categorise stablecoins, the authors use three criteria of crypto-assets: (i) existence of an issuer that is responsible for satisfying any attached claims, (ii) decentralisation or centralisation of responsibilities over the stablecoin initiative and (iii) what underpins the value of a stablecoin and its stability in the currency of reference. So far, the following types of stablecoins have been observed:

- Tokenised funds. An issuer holds funds and is committed to the redeemability of the stablecoins, the safekeeping of the funds by a custodian, centralised responsibilities, e.g. Tether.

- Off-chain collateralised stablecoins. This model is backed by traditional asset classes like securities or commodities, safekeeping of the assets by a custodian, centralised responsibilities.

- On-chain collateralised stablecoins. These are backed by other crypto-assets, with or without an issuer, and have decentralised responsibilities such as the Single Collateral DAI. 
- Algorithmic stablecoins. These are backed by users' expectations about the future purchasing power of their holding; they do not have an issuer but do have decentralised responsibilities, for example NuBits (ECB Crypto-Assets Task Force, 2020, 7).

\section{Initial Libra concept}

The Libra project is governed by the Libra Association under Swiss law. The project is described in a white paper by the Libra Association and in various technical papers. The Libra Association was established by 21 founding members in October 2019. However, eight (including Visa, Mastercard, PayPal and eBay) of the initial 29 partners withdrew due to concerns about meeting regulatory expectations (Brühl, 2020) The intended launch has been delayed as too many regulatory issues remained unanswered.

Libra was conceived as a cryptocurrency backed by a basket of low-volatility assets like bank deposits and short-term government bonds in established fiat currencies (Libra Association, 2019a, 7-8). Libra fits roughly into the category of tokenised funds. The value of the cryptocurrency can fluctuate over time as a consequence of foreign exchange rate movements. Details on the functioning of the Libra Reserve are specified in a technical paper by Calibra staff. ${ }^{1}$ The reserve would be held in a geographically distributed network of custodians with an investment grade credit rating. Users of Libra would not interact with the reserve, instead only 'authorised resellers' (not further specified) would be able to transact large amounts of fiat currency and Libra with the reserve. The Libra Association would mint and destroy coins in response to demand from the authorised resellers. Coins are minted when they purchase Libra and destroyed when they sell Libra at a price depending on the value of the basket of assets. The Libra Association controlling the Libra Reserve would act as a buyer of last resort, but unlike a central bank, would not set any monetary policy (Catalini et al., 2019).

In July 2019, Zetzsche et al. performed a detailed analysis of the Libra project with regards to the business model, corporate governance and regulatory concerns. In particular, the authors criticised the white paper's silence on Libra Networks, a limited liability company under Swiss law already established in April 2019, which would likely be the company seeking regulatory approvals for financial services. It also seems contradictory that fees and divi-

1 In May 2020, the Facebook group rebranded its subsidiary Calibra to Novi, as wallet provider for Libra. See Novi: Welcome to Novi, 26 May 2020, available at https://about.fb.com/news/2020/05/welcome-tonovi/. dend distributions would flow to the members of the association, a non-profit organisation.

For Adachi et al. (2020, 7), ECB staff, the Libra Reserve has the potential to become one of Europe's largest money market funds. The Libra Association disclosed that it would invest in a currency basket made of 50\% USD, $18 \%$ EUR, 14\% JPY, 11\% GBP and 7\% SGD. The share of the euro in the currency basket (18\%) would be larger than the euro area's share of the total user base of Facebook (10\%). This could result in inflows into euro area money markets (Adachi et al., 2020). The ECB Crypto-Assets Task Force differentiates three scenarios for the potential use of stablecoins: "crypto-assets accessory function" (considered as current state of the market), "new payment method" and "alterative store of value". An extensive use of a stablecoin in the scenario, where a stablecoin becomes an ordinary means of payment, could affect the exchange rate channel of monetary policy. In particular, a multi-currency stablecoin like Libra might make it difficult to control domestic developments (ECB Crypto-Assets Task Force, 2020, 17-21).

\section{Regulatory treatment of the initial Libra application under Swiss law}

On 11 September 2019, the Libra Association (2019b) announced that it was seeking a payment system license under Swiss regulation. The Swiss Financial Market Supervisory Authority (FINMA) confirmed this request the same day (FINMA, 2019a). Simultaneously FINMA (2019b) issued a new supplement with criteria for the regulatory treatment of stablecoins under Swiss law. The stablecoin guidelines build upon the general guidelines for initial coin offerings from February 2018 which distinguished between payment, utility and asset function (FINMA, 2018). Libra would be seen as a hybrid token with both payment and asset function.

The stablecoin guidelines from September 2019 cover the regulatory treatment for various categories of stablecoins for indicative purposes, depending on the underlying asset that they are linked to (currencies, commodities, real estate, securities). Potential licensing requirements under the Banking Act or the Collective Investment Schemes Act may apply. The Anti-Money Laundering Act would be applicable for payment tokens and the Financial Market Infrastructure Act would also apply to payment systems of significant importance. Table 1 shows an indicative supervisory classification as a function of the underlying asset to which they are linked.

In the FINMA press release of 11 September 2019, the regulator touched upon requirements likely to be applica- 
Table 1

\section{Categories of stablecoins according to FINMA}

\begin{tabular}{|c|c|c|}
\hline $\begin{array}{l}\text { Cate- } \\
\text { gory }\end{array}$ & Stablecoin linked to & $\begin{array}{l}\text { Indicative supervisory } \\
\text { classification }\end{array}$ \\
\hline 1 & $\begin{array}{l}\text { Fiat currency / cryptocur- } \\
\text { rency with fixed redemption } \\
\text { claim }\end{array}$ & Deposit under banking law \\
\hline 2 & $\begin{array}{l}\text { Basket of fiat currencies } \\
\text { / cryptocurrencies with } \\
\text { redemption claim dependent } \\
\text { on price development }\end{array}$ & $\begin{array}{l}\text { Management of the currency } \\
\text { basket and risk-bearing: } \\
\text { for the account of the issuer: } \\
\text { deposit under banking law; } \\
\text { for the account of the token } \\
\text { holder: collective investment } \\
\text { scheme }\end{array}$ \\
\hline 3 & $\begin{array}{l}\text { Commodity (incl. 'bank } \\
\text { precious metals') with } \\
\text { contractual claim }\end{array}$ & $\begin{array}{l}\text { Bank precious metals: deposit } \\
\text { under banking law; } \\
\text { Commodity: security and } \\
\text { possibly derivative }\end{array}$ \\
\hline 4 & $\begin{array}{l}\text { Basket of commodities (incl. } \\
\text { 'bank precious metals') with } \\
\text { redemption claim dependent } \\
\text { on price development }\end{array}$ & Collective investment scheme \\
\hline 5 & $\begin{array}{l}\text { Commodities (incl. 'bank } \\
\text { precious metals') with } \\
\text { ownership rights }\end{array}$ & $\begin{array}{l}\text { No prudential licensing } \\
\text { requirement }\end{array}$ \\
\hline 6 & $\begin{array}{l}\text { Real estate with redemption } \\
\text { claim dependent on price } \\
\text { development }\end{array}$ & Collective investment scheme \\
\hline 7 & $\begin{array}{l}\text { Specific security with } \\
\text { contractual claim }\end{array}$ & Security and possibly derivative \\
\hline 8 & $\begin{array}{l}\text { Basket of securities with } \\
\text { redemption claim dependent } \\
\text { on price development }\end{array}$ & Collective investment scheme \\
\hline
\end{tabular}

Source: Appendix 2 in FINMA (2019b, 6).

ble to the Libra project. Due to the scope of the project, an internationally coordinated approach would be needed, particularly with regards to the management and governance of the Libra Reserve as well as money laundering issues (FINMA, 2019b).

\section{Libra 2.0 concept}

On 15 April 2020, the Libra Association published an updated Libra concept with a white paper v2.0. The initiators highlight four major changes (Libra Association, 2020, 1-3):

1. "Offering single-currency stablecoins in addition to the multi-currency coin": The Libra network would start with single-currency stablecoins for USD, EUR, GBP and SGD. The multi-currency Libra Coin (LBR) is still planned, but would be made out of single-currency coins being defined in terms of fixed nominal weights (e.g. 50\% USD, 18\% EUR, 11\% GBP, etc.) using a smart contract. Details were not disclosed.

2. "Enhancing the safety of the Libra payment system with a robust compliance framework": Participants would now be distinguished in the categories designated dealers, regulated virtual asset service providers (in a FATF member jurisdiction), certified virtual asset service providers approved by the Libra Association and unhosted wallets (i.e. all the others). The network would start with designated dealers and regulated virtual asset service providers while a certification process is developed.

3. "Forgoing the future transition to a permissionless system while maintaining its key economic properties."

4. "Building strong protections into the design of the Libra Reserve": The Reserve would invest at least $80 \%$ in short-term (up to three months remaining maturity) government securities issued by sovereigns that have very low credit risk (e.g. At rating from S\&P and A1 from Moody's, or higher) and whose securities trade in highly liquid secondary markets. The remaining $20 \%$ would be held in cash, with overnight sweeps into money market funds. Also, the Libra Reserve will get a capital buffer to absorb potential losses from credit, market and operational risks.

On the same day, FINMA confirmed the receipt of an application for a payment system license under Swiss law on the basis of Libra 2.0. FINMA (2020) reiterated that an international approach is required, hence it is in contact with more than 20 supervisory authorities and central banks worldwide and also contributing to working groups and organisations on the development of international standards on global stablecoins.

\section{G7 act on stablecoins}

The Libra announcement in June 2019 moved global stablecoins to the top of the agenda of the G7. The G7 Finance Ministers and Central Bank Governors concluded at a meeting in Chantilly, France, in July 2019, that stablecoins raised serious regulatory and systemic concerns. Stablecoin initiatives and their operators would have to meet the highest standards of financial regulation in order to go ahead without affecting the stability of the financial system. Facebook's project, the big elephant in the room, is not mentioned in the written announcement (G7 France, 2019a). The G7 presidency set up a new G7 Working Group on Stablecoins (G7 France, 2019b). 
In September 2019, the French and German Finance Ministers issued a joint statement warning against the Libra project because the documentation failed to convince them that risks identified by the G7 would be properly addressed. Going even further, the ministers stated that no private entity should claim monetary power inherent to the sovereignty of nations (French Ministry of Economy and German Ministry of Finance, 2019).

At the G7 meeting in Washington in October 2019, G7 Finance Ministers and Central Bank Governors welcomed the report 'Investigating the impact of global stablecoins' by the G7 Working Group on Stablecoins (G7 France, 2019c). The report points out the following critical issues that need to be solved (G7 Working Group on Stablecoins, 2019):

- Stablecoin initiatives must ensure public trust by meeting the highest regulatory standards - including guidance from the international standard-setting bodies - and be subject to prudent supervision and oversight.

- Stablecoin initiatives should demonstrate a sound legal basis to ensure adequate protection and guarantees to all stakeholders and users.

- The governance and risk management framework should ensure operational and cyber resilience.

- The management of the assets underlying the arrangement must be safe, prudent, transparent and consistent with the nature of obligations to the coin holders.

- Stablecoins may raise broader issues for the international monetary system, in particular if they become a widespread substitute for cash and deposits in some economies.

The G7 Working Group on Stablecoins identified challenges and risks of stablecoins for public policy, oversight and regulation regardless of scale as well as inherent in potential global stablecoins (see Table 2). The G7 believes that no global stablecoin project should begin operation until the legal, regulatory and oversight challenges and risks are adequately addressed (G7 France, 2019c).

\section{G20 and standard-setting bodies act on stablecoins}

At their October 2019 meeting in Washington, G20 Finance Ministers and Central Bank Governors took the positions on stablecoins set by the G7. The G20 stated that global stablecoins and other similar arrangements
Table 2

Challenges and risks of stablecoins according to the G7 Working Group on Stablecoins

\begin{tabular}{|c|c|}
\hline & Challenges and risks \\
\hline \multirow{9}{*}{$\begin{array}{l}\text { Challenges and } \\
\text { risks of stable- } \\
\text { coins regardless } \\
\text { of scale }\end{array}$} & Legal certainty \\
\hline & Sound governance \\
\hline & Financial integrity (AML/CFT) \\
\hline & Safety, efficiency and integrity of payment systems \\
\hline & Cyber and other operational risk considerations \\
\hline & Market integrity \\
\hline & Data protection \\
\hline & Consumer/investor protection \\
\hline & Tax compliance \\
\hline \multirow{3}{*}{$\begin{array}{l}\text { Challenges and } \\
\text { risks inherent in } \\
\text { potential global } \\
\text { stablecoins }\end{array}$} & Fair competition in financial markets \\
\hline & Financial stability implications \\
\hline & Monetary policy transmission \\
\hline
\end{tabular}

Source: Authors' own illustration based on G7 Working Group on Stablecoins $(2019,5-15)$

with potential systemic footprints would give rise to serious public policy and regulatory risks (money laundering, illicit finance, and consumer and investor protection) to be evaluated and addressed before the launch (G20 Japan, 2019). In February 2020, the new G20 presidency of Saudi Arabia reiterated that view and asked the Financial Stability Board (FSB), the Committee on Payments and Market Infrastructures (CPMI) and other standard-setting bodies to develop a roadmap to enhance global cross-border payment arrangements by October 2020 (G20 Saudi Arabia, 2020). This is a priority of the upcoming G20 summit in Riyadh (Carstens, 2020, 19).

In October 2019, the FSB Chair, Randal K. Quarles, informed the G20 that the FSB is assessing how the existing regulatory framework applies to global stablecoins and whether any regulatory gaps need to be filled. The FSB formed its own working group on stablecoins (FSB, 2019a). A report on regulatory issues of stablecoins outlines the following steps (FSB, 2019b, 3-4): (i) take stock of existing supervisory and regulatory approaches to stablecoins, (ii) consider whether they are adequate and effective in addressing financial stability and systemic risk concerns, and (iii) advise on possible multilateral responses. In February 2020, the FSB Chair confirmed that the review of approaches in the FSB member jurisdictions was completed and that the FSB has been tasked with coordinating the development of a roadmap for improving cross-border payment systems (FSB, 2020a). To pre- 
pare, the FSB issued a combined report and consultation document in April 2020 on regulatory, supervisory and oversight challenges raised by global stablecoin arrangements (FSB, 2020b). The paper contains a section on risks and vulnerabilities raised by global stablecoins, a summary of the stocktake undertaken in FSB jurisdictions, key standards from various international standard-setting bodies and last but not least ten high-level recommendations to authorities at the jurisdictional level, including the final version of the ten high-level recommendations (FSB, 2020c, 4). The final report was published in October 2020 (FSB, 2020c).

The Financial Action Task Force (FATF) is an international standard-setting body focused on Anti-Money Laundering and Countering the Financing of Terrorism (AML/CFT). In October 2019, the then FATF President Xiangmin Liu informed the G20 that both stablecoins and their service providers would be subject to the FATF standards either as Virtual Assets and Virtual Asset Service Providers or as traditional financial assets and their service providers. The FATF (2019a) intends to actively monitor stablecoins and will consider further clarifications on how the FATF standards apply to stablecoins and their service providers, as well as whether updates are necessary. The FATF issued a report in June 2020 on its analysis of AML/CFT risks associated with stablecoins. The preventive measures in the revised FATF Standards have worked to mitigate risks by so-called stablecoins, so no immediate amendment would be required. The FATF will review the implementation and impact of the revised Standards by June 2021 and consider whether updates are necessary (FATF, 2020).

The International Organization of Securities Commissions (IOSCO) is looking at stablecoins as well. The Chair of the IOSCO Board, Ashley Alder, warned in November 2019 that stablecoins can include features that are typical of regulated securities. Therefore, the IOSCO principles and standards may apply to stablecoins depending on how they are structured, including those related to disclosure, registration, reporting and liability for sponsors and distributors. The IOSCO agrees with the G20 that global stablecoins may give rise to a set of serious public policy and regulatory risks (IOSCO, 2019). In February 2020, the IOSCO published a report on the application of the IOSCO Principles to crypto-assets, without mentioning stablecoins (IOSCO, 2020a). A report on global stablecoin initiatives was issued a month later (IOSCO, 2020b). The paper defines a hypothetical case study which is reminiscent of Libra and explores how the existing IOSCO principles and standards apply. It also contains a preliminary analysis of the application of the CPMI-IOSCO Principles for Financial Markets Infrastructures (PFMI) to three highlevel cases of stablecoin arrangements.

\section{European Union institutions act on stablecoins}

In December 2019, the Council of the European Union and the European Commission issued a joint statement on stablecoins based on the strict positions already articulated by the G7 and the G20. The EU institutions would act in cooperation with the ECB and with national and European supervisory authorities. The Council and the Commission are willing to take all necessary measures to ensure appropriate standards of consumer protection and orderly monetary and financial conditions. No global stablecoin arrangement should begin operation in the EU until the legal, regulatory and oversight challenges and risks are adequately identified and addressed (Council of the European Union, 2019).

The European Commission also launched a consultation on crypto-assets in December 2019 which ran until March 2020. Eight of the 117 questions relate to stablecoins. The findings would be considered for new EU legislation on crypto-assets including stablecoins (European Commission, 2019, 5).

Concerning the current EU regulatory framework, a research note by ECB staff pointed out that a stablecoin arrangement could fall under a number of frameworks or none of them (in the latter case meaning a potential regulatory gap) (Adachi et al., 2020). Firstly, the stablecoin may qualify as e-money, hence the Second Electronic Money Directive would apply for the coin and its issuer. Secondly, the asset management function (e.g. Libra Reserve) may qualify as an investment fund, therefore the UCITS Directive, the AIFM Directive and the Money Market Fund Regulation (EU) may apply. Thirdly, the stablecoin may be regarded as equivalent to a deposit, so EU banking regulation may apply.

A detailed study by the University of Antwerp requested by the European Parliament's Committee on Economic and Monetary Affairs, published in April 2020, recommends rulemaking on crypto-assets including global stablecoins at the EU level to avoid regulatory arbitrage due to national initiatives that are not aligned (European Commission, 2019).

In September 2020 an early draft version of a proposal for a regulation on Markets in Crypto-assets (MiCA) by the European Commission was leaked on the journalistic website politico.eu. The MiCA acronym draws an analogy to the Markets in Financial Instruments Directive (MiFID II). Sven Giegold, Member of the European Parliament, confirmed the authenticity of the leak and informed that the ECON adopted a report proposing a regulation of crypto-assets (Giegold, 2020). 
On 24 September 2020 the European Commission announced the adoption of a new Digital Finance Package which includes a Digital Finance Strategy, a Retail Payments Strategy, a legislative proposal on digital operational resilience, and a provisional version of the MiCA legislative proposal (leaked two weeks before). The press release states (European Commission, 2020a) that the MiCA regulation should protect investors from risks and provide legal clarity and certainty for crypto-asset issuers and providers. The MiCA proposal document itself (European Commission, 2020b) is accompanied by provisional versions of the annexes (European Commission, 2020c), an impact assessment (European Commission, 2020d) and an executive summary of the impact assessment (European Commission, 2020e).

The Commission stated that crypto-assets already subject to EU legislation would remain like that. For previously unregulated crypto-assets the Commission proposes a bespoke regime setting strict requirements for issuers of crypto-assets and crypto-asset service providers. Safeguards include capital requirements, custody of assets, a mandatory complaint holder procedure available to investors, and rights of the investor against the issuer. Issuers of global stablecoins would be subject to more stringent capital requirements, liquidity management and interoperability requirements.

On 2 October 2020 the ECB published a report prepared by the Eurosystem High-Level Task Force on central bank digital currency (CBDC) on the possible issuance of a digital euro. The task force, made of experts from the ECB and the 19 national central banks of the euro area, identified possible scenarios that would require the issuance of a digital euro. A public consultation would start on 12 October 2020 in parallel with experimentation, without prejudice to the final decision by the Governing Council of the ECB (ECB, 2020a). By mid-2021 a decision would be taken whether to launch a digital euro project (ECB, $2020 \mathrm{~b}, 6$ ). Although Libra itself is only mentioned in one footnote of the report, there is no doubt that the timing and the speed of the digital euro initiative is a reaction to the perceived threat posed by this global stablecoin project.

\section{Outlook}

Politicians and regulators have no interest in allowing the rise of a global stablecoin to impact monetary policy and financial stability. It is unclear whether Libra 2.0 will actually launch successfully. This will depend on how high the regulators worldwide are willing to raise the bar. At European level a clear message against the Libra project has just been sent with the MiCA regulation proposal by the European Commission and the announcement of a digital euro initiative by the ECB.

\section{References}

Adachi, M., M. Cominetta, C. Kaufmann and A. van der Kraaij (2020), $A$ regulatory and financial stability perspective on global stablecoins, ECB Macroprudential Bulletin, 10, https://www.ecb.europa. eu/pub/financial-stability/macroprudential-bulletin/html/ecb. mpbu202005_1 3e9ac10eb1.en.html (4 September 2020).

Adrian, T. and T. Mancini-Griffoli (2019), The rise of digital money, IMF FinTech Notes, 19/001, https://www.imf.org/en/Publications/fintechnotes/Issues/2019/07/12/The-Rise-of-Digital-Money-47097 (4 September 2020).

Brühl, V. (2020), Libra - A Differentiated View on Facebook's Virtual Currency Project, Intereconomics, 55 (1), https://www.intereconomics.eu/ contents/year/2020/number/1/article/libra-a-differentiated-view-onfacebook-s-virtual-currency-project.html (4 September 2020).

Bullmann, D., J. Klemm and A. Pinna (2019), In search for stability in crypto-assets: are stablecoins the solution?, ECB Occasional Paper Series, 230, https://www.ecb.europa.eu/pub/pdf/scpops/ecb. op230 d57946be3b.en.pdf (4 September 2020).

Carstens, A. (2020), Shaping the future of payments, BIS Quarterly Review, March, https://www.bis.org/publ/qtrpdf/r_qt2003e.pdf (4 September 2020).

Catalini, C., O. Gratry, J. M. Hou, S. Parasuraman and N. Wernerfelt (2019), The Libra Reserve, Calibra staff paper, https://libra.org/en-US/ wp-content/uploads/sites/23/2019/06/TheLibraReserve_en_US.pdf (4 September 2020).

Council of the European Union (2019, 5 December), Joint statement by the Council and the Commission on "stablecoins", Press release, https://www.consilium.europa.eu/en/press/press-releases/2019/12/05/ joint-statement-by-the-council-and-the-commission-on-stablecoins/ (4 September 2020).

ECB (2020a, 2 October), ECB intensifies its work on a digital euro, https://www. ecb.europa.eu/press/pr/date/2020/html/ecb.pr201002 f90bfc94a8. en.html (30 October 2020).

ECB (2020b, October), Report on a digital euro, https://www.ecb.europa. eu/euro/html/digitaleuro-report.en.html and https://www.ecb.europa. eu/pub/pdf/other/Report_on_a_digital_euro 4d7268b458.en.pdf (30 October 2020).

ECB Crypto-Assets Task Force (2019), Crypto-Assets: Implications for financial stability, monetary policy, and payments and market infrastructures, ECB Occasional Paper Series, 223, https://www.ecb.europa.eu/pub/pdf/scpops/ecb.op223 3ce14e986c.en.pdf (4 September 2020).

ECB Crypto-Assets Task Force (2020), Stablecoins: Implications for monetary policy, financial stability, market infrastructure and payments, and banking supervision in the euro area, Occasional Paper Series, 247, September 2020, https://www.ecb.europa.eu/pub/pdf/ scpops/ecb.op247 fe3df92991.en.pdf (15 October 2020).

European Commission (2019), On an EU framework for markets in crypto-assets, consultation document, https://ec.europa.eu/info/ sites/info/files/business_economy_euro/banking_and_finance/ documents/2019-crypto-assets-consultation-document_en.pdf (4 September 2020).

European Commission (2020a), Digital Finance Package: Commission sets out new, ambitious approach to encourage responsible innovation to benefit consumers and businesses, press release, $24 \mathrm{Sep}$ tember, https://ec.europa.eu/commission/presscorner/detail/en/ IP_20_1684 (15 October 2020).

European Commission (2020b), Proposal for a Regulation of the European Parliament and the Council on Markets in Crypto-assets, and amending Directive (EU) 2019/1937, COM(2020) 593 final, 24 September, http://ec.europa.eu/finance/docs/law/200924-crypto-assetsproposal_en.pdf (15 October 2020).

European Commission (2020c), Annexes to the Proposal for a Regulation of the European Parliament and the Council on Markets in Cryptoassets, and amending Directive (EU) 2019/1937, COM(2020) 593 final 
Annexes 1 to 6, 24 September, http://ec.europa.eu/finance/docs/ law/200924-crypto-assets-proposal-annex_en.pdf (15 October 2020).

European Commission (2020d), Commission Staff Working Document Impact Assessment Accompanying the document Proposal for a Regulation of the European Parliament and of the Council on Markets in Crypto-assets and amending Directive (EU) 2019/1937, SWD(2020) 380 final, 24 September, http://ec.europa.eu/finance/docs/ law/200924-crypto-assets-proposal-impact-assessment_en.pdf (15 October 2020).

European Commission (2020e), Commission Staff Working Document Executive Summary of the Impact Assessment Accompanying the document Proposal for a Regulation of the European Parliament and of the Council on Markets in Crypto-assets and amending Directive (EU) 2019/1937, SWD(2020) 381 final, 24 September, http://ec.europa. eu/finance/docs/law/200924-crypto-assets-proposal-impact-assessment-summary_en.pdf (15 October 2020).

European Securities and Markets Authority (2019), ESMA Report on Trends, Risks and Vulnerabilities, 2, https://www.esma.europa.eu/ sites/default/files/library/esma_50-165-883_report_on_trends_ risks_and_vulnerabilities_no.2_2019.pdf (4 September 2020).

Financial Action Task Force (2019a, 3 October), Letter from FATF President Mr. Liu to Mr. Aso, Minister of Finance Japan, https://www.boj. or.jp/en/announcements/release_2019/data/rel191021e3.pdf (4 September 2020).

Financial Stability Board (2019a, 13 October), FSB Chair's letter to G20 Finance Ministers and Central Bank Governors, https://www.fsb. org/2019/10/fsb-chairs-letter-to-g20-finance-ministers-and-centralbank-governors-october-2019/ (4 September 2020).

Financial Stability Board (2019b, 18 October), Regulatory issues of stablecoins, https://www.fsb.org/2019/10/regulatory-issues-of-stablecoins/ (4 September 2020).

Financial Stability Board (2020a, 18 February), FSB Chair's letter to G20 Finance Ministers and Central Bank Governors, letter from the FSB chair, https://www.fsb.org/2020/02/fsb-chairs-letter-to-g20-financeministers-and-central-bank-governors-february-2020/ (4 September 2020).

Financial Stability Board (2020b, 14 April), Addressing the regulatory, supervisory and oversight challenges raised by "global stablecoin" arrangements, Consultative document, https://www.fsb.org/2020/04/ addressing-the-regulatory-supervisory-and-oversight-challengesraised-by-global-stablecoin-arrangements-consultative-document/ (4 September 2020)

Financial Stability Board (2020c, 13 October), Regulation, Supervision and Oversight of "Global Stablecoin" Arrangements, Final Report and High-Level Recommendations, https://www.fsb.org/2020/10/regulation-supervision-and-oversight-of-global-stablecoin-arrangements/ (14 October 2020)

FINMA (2018), Guidelines for enquiries regarding the regulatory framework for initial coin offerings (ICOs), https://www.finma.ch/en/ news/2018/02/20180216-mm-ico-wegleitung/ (4 September 2020).

FINMA (2019a, 11 September), FINMA publishes 'stable coin' guidelines, Press release, https://www.finma.ch/en/news/2019/09/20190911mm-stable-coins/ (4 September 2020).

FINMA (2019b), Supplement to the guidelines for enquiries regarding the regulatory framework for initial coin offerings (ICOs), https:// www.finma.ch/en/ /media/finma/dokumente/dokumentencenter/ myfinma/1bewilligung/fintech/wegleitung-stable-coins.pdf?la=en (4 September 2020).

FINMA (2020, 15 April), Libra Association: FINMA licensing process initiated, Press release, https://www.finma.ch/en/news/2020/04/20200416mm-libra/ (4 September 2020).

French Ministry of Economy and German Ministry of Finance (2019, 13 September), Joint Statement on Libra, https://www.bundesfinanzministerium.de/Content/EN/Standardartikel/Topics/Financial_markets/Articles/2019-09-17-Libra.html (4 September 2020).

G7 France (2019a), Chair's Summary: G7 Finance Ministers and Central Bank Governors‘ Meeting, Chantilly, 17-18 July 2019, https://www. banque-france.fr/sites/default/files/media/2019/08/02/g7_chairs_ summary_vff_en.pdf (4 September 2020).

G7 France (2019b, 18 July), Update from the Chair of the G7 working group on stablecoins to G7 Finance Ministers and Central Bank Gov- ernors Meeting, https://www.bis.org/cpmi/speeches/sp190718.htm (4 September 2020).

G7 France (2019c, 17 October), Chair's Statement on Stablecoins, Washington, https://www.mof.go.jp/english/international_policy/convention/g7/g7_20191017_01.pdf (4 September 2020).

G7 Working Group on Stablecoins (2019), Investigating the impact of global stablecoins, October 2019, https://www.bis.org/cpmi/publ/ d187.pdf (4 September 2020).

G20 Japan (2019), G20 Press Release on Global Stablecoins, 1, https://www.mof.go.jp/english/international_policy/convention/g20/ g20_191018sc.htm (4 September 2020).

G20 Saudi Arabia (2020), G20 Finance Ministers and Central Bank Governors Meeting, Riyadh, 22-23 February 2020, Communiqué, https:// g20.org/en/g20/Documents/Communique\%CC\%81\%20Final\%202223\%20February\%202020.pdf (4 September 2020).

Giegold, S. (2020), Important step towards a regulation of Bitcoin, Libra \& Co., 11 September, available at https://sven-giegold.de/en/digitalfinance-at-econ/ (15 October 2020).

International Monetary Fund (2019, 14 May), Stablecoins, Central Bank Digital Currencies, and Cross-Border Payments: A New Look at the International Monetary System, Remarks by Tobias Adrian at the IMF-Swiss National Bank Conference, Zurich, https://www.imf.org/ en/News/Articles/2019/05/13/sp051419-stablecoins-central-bankdigital-currencies-and-cross-border-payments (4 September 2020).

International Organization of Securities Commissions (2019, 4 November), Statement on IOSCO study of emerging global stablecoin proposals, https://www.iosco.org/news/pdf/IOSCONEWS550.pdf (4 September 2020).

International Organization of Securities Commissions (2020a), Issues, Risks and Regulatory Considerations Relating to Crypto-Asset Trading Platforms, Final Report, FR02/2020, https://www.iosco.org/library/pubdocs/pdf/IOSCOPD649.pdf (4 September 2020).

International Organization of Securities Commissions (2020b), Global Stablecoin Initiatives, Public Report, OR01/2020, https://www.iosco. org/library/pubdocs/pdf/IOSCOPD650.pdf (4 September 2020).

Libra Association (2019a, 14 June), An Introduction to Libra, White Paper, https://libra.org/en-US/wp-content/uploads/sites/23/2019/06/ LibraWhitePaper_en_US.pdf (4 September 2020).

Libra Association (2019b, 11 September), Libra Association Pursues Payment System License Under FINMA Lead Supervision, Libra Communiqué, https://libra.org/en-US/wp-content/uploads/sites/23/2019/09/ Libra-Communique\%CC\%81.pdf (4 September 2020).

Libra Association (2020), Libra, White Paper v2.0, https://libra.org/en-US/ white-paper/ (4 September 2020).

Mancini-Griffoli, T. et al. (2018), Casting Light on Central Bank Digital Currency, IMF Staff Discussion Notes, 18/08, https://www.imf.org/en/Publications/Staff-Discussion-Notes/Issues/2018/11/13/Casting-Lighton-Central-Bank-Digital-Currencies-46233 (4 September 2020).

Zetzsche, D. A., R. P. Buckley and D. W. Arner (2019), Regulating Libra: The Transformative Potential of Facebook's Cryptocurrency and Possible Regulatory Responses, University of Hong Kong Faculty of Law Research Paper, 2019/042, https://ssrn.com/abstract=3414401 (20 October 2019). 